\title{
Perceived Stress, Social Support and Social Media Addiction in University Students During COVID-19 Pandemic
}

\author{
COVID-19 Pandemisi Sırasında Üniversite Öğrencilerinde Algılanan Stres, Sosyal \\ Destek ve Sosyal Medya Bağımlılığı
}

\author{
(1) Filiz TAȘ ${ }^{1}$ \\ ${ }^{1}$ Kahramanmaraş Sütçü İmam University Faculty of Health Sciences, Public Health Nursing, Kahramanmaraş, Turkey
}

\section{Abstract}

Objective: The purpose of the study is to examine the relationship between perceived stress, perceived social support and social media addiction in university students.

Method: The research is a descriptive, relational study. The sample consisted of 404 students studying at the Faculty of Health Sciences. Personal Information Form, Perceived Stress Scale, Perceived Social Support Scale, and Social Media Addiction Scale-Adult Form were used for data.

Results: During the pandemic period, $71.8 \%$ of students used their mobile phones for study. $73.8 \%$ stated that their study hours have decreased. $94.1 \%$ of the students stated that the time spent at home increased, and $91.8 \%$ stated that there was an increase in the hours of using a computer or phone due to the pandemic. There were significant differences between perceived stress, social support, and social media addiction levels according to various demographic variables.

Conclusion: The results showed that $86.9 \%$ of students increased their time spent online during the pandemic period. It was concluded that perceived stress and social support affect social media addiction.

Keywords: COVID-19, students, stress, social support, social media addiction

\section{$\ddot{0} z$}

Amaç: Araştırmanın amacı, üniversite öğrencilerinde algılanan stres, algılanan sosyal destek ve sosyal medya bağımlılı̆̆ı arasındaki ilişkiyi incelemektir. Yöntem: Araștırma, tanımlayıcı ilișkisel bir çalıșmadır. Örneklemi Sağlık Bilimleri Fakültesi’nde öğrenim gören 404 öğrenci olușturdu. Veriler için Kișisel Bilgi Formu, Algılanan Stres Ölçeği, Algılanan Sosyal Destek Ölçeği ve Sosyal Medya Bağımlılığı Ölçeği-Yetișkin Formu kullanıldı.

Bulgular: Pandemi döneminde öğrencilerin \%71,8'i ders çalışmak için cep telefonlarını kullandı. \%73,8’i çalışma saatlerinin azaldığını, \%94,1'i evde geçirilen zamanın arttığını, \%91,8’i ise pandemi nedeniyle bilgisayar veya telefon kullanma saatlerinde artış olduğunu belirtti. Algılanan stres, sosyal destek ve sosyal medya bağımlılık düzeyleri arasında çeșitli demografik değișkenlere göre anlamlı farklılıklar olduğu bulunmuștur.

Sonuç: Sonuçlar, öğrencilerin \%86,9’unun pandemi döneminde internette geçirdikleri zamanın artırdığını gösterdi. Algılanan stres ve sosyal desteğin sosyal medya bağımlılı̆̆ını etkilediği sonucuna varıldı.

Anahtar kelimeler: COVID-19, öğrenciler, stres, sosyal destek, sosyal medya bağımlılı̆̆ 


\section{Introduction}

The Coronavirus (COVID-19) that emerged unexpectedly in Turkey as well as all over the world, due to the epidemic, faceto-face education in universities was transformed into distance education, and the lifestyle and education life of all students changed (1). This unexpected and sudden situation caused the students to go out of their routines.

Stress occurs when the danger of impaired hemostasis is perceived $(2,3)$. While stress can occur for many physical reasons, it can also occur for emotional reasons $(4,5)$. The causes of stress vary from person to person. The stress response has complex physiological and behavioral effects in the organism (5). It is not possible to completely eliminate stress in daily life. However, some environmental factors and emotional situations are effective in the effects of stress and the ability to manage stress $(5,6)$. The COVID-19 pandemic has become the most stressful event worldwide and presents a global challenge not only for the medically contagious disease but also for mental health $(1,7)$. Measures taken by countries to reduce health problems related to morbidity and mortality caused by the COVID-19 epidemic, physical distancing, and stay-at-home orders negatively affected individuals $(7,8)$. During the COVID-19 epidemic, computers and the internet as information technology became indispensable in every aspect of daily life (9). With the emergence of web2.0 technologies run over the Internet, individuals have become social network users(10). Today, the internet and social media applications have become a popular tool used by children, especially young people and adults (11).

Internetand informationtechnologieshavebecomeindispensable during the epidemic period due to their widespread use in many countries around the World (11-13). Excessive or problematic use of the internet and social media $(10,12)$ and spending at least 8.5 to 21.5 hours a week online are considered addictions (13). Social media is a collaborative term for websites and online tools that provide users with the opportunity to interact and share information and ideas (14). Considering the purposes of internet usage in Turkey, it is reported that the most preferred ones are YouTube, Instagram, Whatsapp, Facebook Twitter, respectively, with the use of social media in the first place (15). Social media addiction is when people get stressed when they are away from social media, they panic, they feel insecure $(15,16)$. Social media addiction can cause mental health problems such as social phobia, social anxiety disorder, social appearance anxiety (17).

The World Stats 2021 research reports that the number of internet users worldwide has reached approximately 5 billion 168 million (65. 6\%) (18). Internet usage rate in Europe is reported as $88.2 \%$ and social media usage as $60.3 \%$ (18). According to the same research, the internet usage rate in Turkey is $81.3 \%$ and the social media user rate is $67.3 \%$ (18). According to the 2020 statistical report published jointly by we are Social and Hootsuite (19), $74.0 \%$ of Turkey's population is internet and $64.0 \%$ is social media users. It is stated that internet users spend 7.5 hours on the internet and 3 hours on social media (19). In the same report, it is reported that the rate of social media use in the 18-24 age group is $7.3 \%$ for women and $13.2 \%$ for men [19]. After the World Health Organization, declared a global epidemic on March 11, 2020, all higher education institutions were suspended on March 16 (17), As of March 23, all universities switched to distance education (20).

Due to the urgent processes during the pandemic period, students had stressful processes due to both the effect of the worrying environment created by the pandemic and the distance education method they had not encountered before (21). Stress affects the normal functions of people negatively, as well as being exposed to stress for a long time causes various health problems in people (22).

The role of social support as a source of coping with stress and protection against diseases many studies have reported that social support has a positive relationship with mental and physical health (14,23-25).

In recent years, the development and active use of the internet and mobile phones has led to the spread of social media, which is one of the communication tools (14). Social networks, which create the effect of face-to-face communication in the virtual environment, have become one of the most important branches of the internet (14). Many functions of social media, such as connecting with friends, finding new friends, sharing photos, videos and blog content, cause young people to use social media intensively (23). Internet in general and social media platforms in particular, besides providing support for the development of individuals, their uncontrolled use can lead to addiction (26).

As it can be said for each of the technological addictions, it may be inevitable for university-age individuals to spend excessive time on social media and accordingly to have problems in fulfilling their personal, social, educational and professional responsibilities. Studies examining the relationship between Internet social media use, technology addictions and stress and social support are limited. For this reason, it is important to examine the relationship between students' stress levels, social support status and social media addiction levels.

\section{METHODS}

\section{Sample}

This research is a descriptive, relational questionnaire-based study. The population of the research consisted of the $2^{\text {nd }}, 3^{\text {rd }}$ and $4^{\text {th }}$-grade students of the Nursing and Midwifery departments 
of a state university studying at the Faculty of Health Sciences ( $\mathrm{N}: 516)$. The sample population was determined as a minimum of 220 with a known sampling method with a probability of $95 \%$ and a margin of error of 5\%. The study data was completed with 404 students who accepted to participate in the research and filled out all the forms (participation rate 78\%).

Inclusion criteria of students were being a student of the faculty of health sciences and having taken the previous semester (spring semester) courses by distance education method. Exclusion criteria were bein first-year students who have just started their university education and have not taken distance education before ( $\mathrm{N}$ : 170).

\section{Procedure}

The research data were collected with google form and online forms. All the forms were sent to class Whatsapp groups at the same time through class representatives. The forms consisted of four parts. The first part consisted of 15 questions to describe the students' socio-demographic characteristics and internet usage characteristics. The second part consisted of the perceived stress scale (14 items), the third part consisted of the perceived social support scale (12 items), and the fourth part consisted of the social media addiction scale (20 items).

An informed consent form explaining the purpose of the study was sent to the students before they filled out the questionnaires. They were informed that they could participate in the study voluntarily. In addition to this, in the online form prepared, the first question "Do you agree to participate in the study?" was formed and their consent was obtained in this way. The online form, which each participant can fill in approximately 20-25 minutes, consists of 61 questions and has been arranged so that the participants can see all the questions at the same time after logging in. Within the scope of the study, to prevent the same participants from filling out the survey again, the Google Forms settings of the participants were enabled to limit the answers to one answer feature, allowing each participant to answer once. To prevent data loss, Forms settings have been adjusted to keep any questions from being left blank. In this way, it was obligatory to answer all questions.

Research data were collected between October and November 2020. Reminder messages were sent to students every 10 days to fill out the forms. Ethical approval of the study was received on 09.09.2020 from Kahramanmaraş Sütçü İmam University Faculty of Medicine Nonclinical Research Ethics Committee. (decision number, 2020/17-16). "Personal Information Form", "Perceived Stress Scale", "Perceived Social Support Scale" and "Social Media Addiction Scale-Adult Form" were used to collect the data of the study.

\section{Measures}

\section{Personal Information Form}

The form consists of 15 questions including socio-demographic characteristics of individuals and their use of technological devices (age, gender, class, study style, use of technological tools, social media memberships, time spent in social media, etc.). The personal information form was prepared by the researcher in line with the literature (1,10-15).

\section{Perceived Stress Scale (PSS)}

The original version of the Perceived Stress Scale was developed by Cohen Kamarck and Mermelstein (1983) to determine the stress perceptions of individuals regarding various situations in their lives. Turkish validity of the scale was conducted by Eskin et al., (2013). The scale, which consists of 14 items in total, evaluates students' perceptions of stress regarding the learning environment through 5-point Likert-type items ranging from "never (0)" to "very often (4)". 7 items with positive statements (item numbers: $4,5,6,7,9,10,13$ ) are scored in reverse. The scores of PSS range from 0 to 56. A high score from the scale indicates an excess of the student's perception of stress (22). The perceived stress scale Cronbach's alpha value was reported as 0.84 .

\section{Perceived Social Support Scale (PSSS)}

Original scale Zimet et al.,(1988) have been developed. The Turkish validity and reliability of the scale were done by Eker Arkar and Yaldız (2001). The scale is a 12-item scale. It includes 3 groups related to the source of the support, each of which consists of 4 items. These; family, friends, and a special person. Each item was evaluated using a 7-grade. The subscale score is obtained by summing the scores of the four items in each subscale. The total score of the scale is obtained by summing the subscale scores. A high score indicates high perceived social support (25). The Cronbach alpha value of the perceived social support scale was reported as 0.85 .

\section{Social Media Addiction Scale-Adult Form (SMAS-AF)}

The Social Media Addiction Scale, the validity and reliability of which was made by Şahin and YağcI (2017), is a scale consisting of two sub-dimensions and a total of 20 items. A five-point rating was used in the scale as "1-Not suitable for me at all", "2-Not suitable for me", "3- Undecided" "4- Suitable for me", "5Very suitable for me". Negative expressions were reverse coded. Items 5 and 11 are reverse scored. The scale is divided into two sub-dimensions. The virtual tolerance sub-dimension consists of items 1-11, and the virtual communication sub-dimension consists of items 12-20. The lowest score that can be obtained from the scale is 20 , and the highest score is 100 . A high score is considered as a social media addict (10). The Cronbach's alpha internal consistency coefficient for the overall scale was reported as 0.94 . 


\section{Data analysis}

SPSS 25.0 (Statistical Package for Social Science) package program was used to evaluate the data. In this study, the number of units (n), percentage (\%), mean (standard deviation), minimum and maximum were given as summary statistics. The normal distribution of the data was evaluated by the Kolmogorov Smirnov test and Q-Q graph. Cronbach's alpha method was used to determine the reliability of the scales used. An Independent t-test was used in the comparison of binary variables in the statistical analysis of the study since the data were normally distributed. One-Way Anova test was used for comparison with three or more variables. Tukey HSD multiple comparison tests was used for differences between groups. It was decided whether there was a significant relationship between the scales by using correlation analysis. Pearson correlation test was applied in the correlation relationship since the data had a normal distribution. In the evaluations, $\mathrm{p}<0.05$ was accepted as the level of significance.

\section{Results}

In this study, Cronbach's alpha values were 0.88 for the Perceived Stress Scale, 0.91 for the Perceived Social Support Scale, and 0.91 for the Social Media Addiction Scale. Perceived stress scale, Perceived social support scale and Social media addiction scale; Since the KMO value was greater than 0.80 , the value obtained was evaluated as "very good" for factor analysis.

Students scored above the average on the "Perceived stress" (32.14 \pm 7.83$)$, "Perceived social support" 52.23 \pm 17.73 , and "Social Media Addiction scales 56.29 \pm 16.55 .
They got $19.30 \pm 7.15$ points from the "Family" dimension and $19.33 \pm 7.11$ points from the "Friends" dimension, which is one of the sub-dimensions of the social support scale, and their scores are above the average. They got a moderate score of $13.59 \pm 8.69$ from the "special person" sub-dimension.

They scored 33.68 \pm 9.81 high in the "Virtual tolerance" subdimension of social media addiction, and $22.60 \pm 8.18$ low in the "Virtual communication" sub-dimension (Table 1)

The mean age of the students was $20.8 \pm 1.70$. The youngest student is 18 years old and the oldest is 34 years old. It was determined that $85.4 \%$ were female, $97.0 \%$ were single, $56.9 \%$ were in the nursing department, $40.6 \%$ were in the second year, $59.9 \%$ lived in the city center for a long time, $80.7 \%$ had medium economic status (Table 2).

$71.8 \%$ of students had used cell phones for the study, $73.8 \%$ pandemic during the course of working hours is reduced, the pandemic of $94.1 \%$ during that increased time spent at home, in the hours of use due to the pandemic of $91.8 \%$ computer or telephone said that increase. $97.5 \%$ of them stated that they have a smartphone, $86.6 \%$ of them used Instagram $57.7 \%$ of them youtube $47.0 \%$ of them Twitter $24.5 \%$ of them Facebook social networks. $86.9 \%$ of the students reported that the time spent on the internet increased during the pandemic period compared to before. Social networking sites, instant messaging programs, online games, and all other websites, 36.9\% reported that they spent an average of 3-4 hours $22.5 \%$, 5-6 hours $14.9 \%$ seven hours or more in a day (Table 3).

According to age groups, students in the 21-23 age group have higher perceived stress scores than $33.08 \pm 7.67$ other

Table 1. Mean scores, factor loads and cronbach's alpha $(\alpha)$ results of the scales

\begin{tabular}{|c|c|c|c|c|c|c|}
\hline Scales & Factors & Min-Max & $\bar{x} \pm$ Ss & $\begin{array}{l}\text { Factor Load } \\
\text { Range }\end{array}$ & $\begin{array}{l}\text { Explained } \\
\text { Variance }\end{array}$ & $\begin{array}{l}\text { Cronbach Alpha } \\
(\alpha)\end{array}$ \\
\hline \multirow[t]{2}{*}{ Perceived Stress Scale } & $\begin{array}{l}\text { Perceived } \\
\text { Stress Scale }\end{array}$ & $0-56$ & $32.14 \pm 7.83$ & $1.092-.454$ & $61.36 \pm 7.83$ & 0.88 \\
\hline & \multicolumn{6}{|c|}{ KMO: .906; Bartlett: 2496.690; df: 91; p: .000 } \\
\hline \multirow{5}{*}{$\begin{array}{l}\text { Perceived Social Support } \\
\text { Scale }\end{array}$} & Family & $4-28$ & $19.30 \pm 7.15$ & $.634-.898$ & $51.22 \pm 7.15$ & 0.91 \\
\hline & Friend & $4-28$ & $19.33 \pm 7.11$ & $.465-.480$ & $50.68 \pm 7.11$ & 0.93 \\
\hline & Special Person & $4-28$ & $13.59 \pm 8.69$ & $.173-.327$ & $75.62 \pm 8.69$ & 0.95 \\
\hline & Total & $12-84$ & $52.23 \pm 17.73$ & $1.814-963$ & $316.36 \pm 17.78$ & 0.91 \\
\hline & \multicolumn{6}{|c|}{ KMO: .878; Bartlett: 4788.900; df: 66; p: .000 } \\
\hline \multirow{4}{*}{$\begin{array}{l}\text { Social Media Addiction } \\
\text { Scale }\end{array}$} & Virtual Tolerance & $10-50$ & $33.68 \pm 9.81$ & $1.079-.733$ & $96.35 \pm 9.81$ & 0.86 \\
\hline & $\begin{array}{l}\text { Virtual } \\
\text { Communication }\end{array}$ & $10-50$ & $22.60 \pm 8.18$ & $1.401-.489$ & $66.98 \pm 8.18$ & 0.87 \\
\hline & Total & $20-100$ & $56.29 \pm 16.55$ & $1.869-.993$ & $274.18 \pm 16.55$ & 0.91 \\
\hline & \multicolumn{6}{|c|}{ KMO: .924; Bartlett: 3801.313; df:190; p: .000 } \\
\hline
\end{tabular}


Table 2. Distribution of students' demographic data

\begin{tabular}{|c|c|c|}
\hline Data & $N$ & $\%$ \\
\hline \multicolumn{3}{|c|}{ Age $20.8 \pm 1.70$} \\
\hline \multicolumn{3}{|l|}{ Gender } \\
\hline Female & 345 & 85.4 \\
\hline Male & 59 & 14.6 \\
\hline \multicolumn{3}{|c|}{ Marital status } \\
\hline Single & 392 & 97.0 \\
\hline The married & 12 & 3.0 \\
\hline \multicolumn{3}{|l|}{ Department } \\
\hline Nursing & 230 & 56.9 \\
\hline Midwifery & 174 & 43.1 \\
\hline \multicolumn{3}{|l|}{ Class } \\
\hline 2. class & 164 & 40.6 \\
\hline 3. class & 104 & 25.7 \\
\hline 4 class & 136 & 33.7 \\
\hline \multicolumn{3}{|l|}{ Living place } \\
\hline City center & 242 & 59.9 \\
\hline District & 97 & 24.0 \\
\hline Village & 65 & 16.1 \\
\hline \multicolumn{3}{|c|}{ Economic Status } \\
\hline Low & 69 & 17.1 \\
\hline Middle & 326 & 80.7 \\
\hline High & 9 & 2.2 \\
\hline
\end{tabular}

age groups, and the difference was not significant $(p>0.05)$. Perceived stress scores of midwifery students were higher than $33.79 \pm 8.24$ nursing students $30.90 \pm 7.29$ and the difference was significant $(p<0.00)$. In terms of class scores, the perceived stress scores and social media scores of the $4^{\text {th }}$-grade students were higher than the students in the other class, but there was no significant difference between them ( $p>0.05)$. Perceived Stress in women was $32.56 \pm 7.84$ higher than in men $29.75 \pm 7.43$ and the difference was significant $(\mathrm{t}=2.565 ; p<0.011)$.

The Perceived Social Support score was $52.94 \pm 18.61$ in the midwifery department students compared to $51.69 \pm 17.15$ in the nursing department students and there was no difference. $(p>0.05)$ The Social support score was $52.95 \pm 17.62$ in females and $48.00 \pm 18.32$ in males and the difference was significant $(\mathrm{t}=1.986 ; p<0.048)$. Perceived Social Support scores were determined as $55.00 \pm 10.71$ in single students and $51.62 \pm 17.63$ in married students and the difference was significant $(\mathrm{t}=3.997$; $p<0.00)$.

It was determined that social media addiction differed significantly according to age groups (21-23 age group $58.68 \pm 16.78$ points) and place of residence $56.29 \pm 19.81$ points for those living in the district) $(p<0.005)$. It was observed that social media addiction did not differ between departments and according to gender ( $p>0.005)$. (Table 4$)$.

Table 3. Technological equipment use and characteristics of students during the pandemic period

\begin{tabular}{|c|c|c|}
\hline Data & $\mathrm{N}$ & $\%$ \\
\hline \multicolumn{3}{|c|}{ The way you study during the pandemic? } \\
\hline $\begin{array}{l}\text { Mobile phones } \\
\text { Book } \\
\text { Computer }\end{array}$ & $\begin{array}{l}290 \\
199 \\
141\end{array}$ & $\begin{array}{l}71.8 \\
50.5 \\
34.9\end{array}$ \\
\hline \multicolumn{3}{|c|}{ Change in working hours } \\
\hline $\begin{array}{l}\text { Decreased } \\
\text { Hasn't changed } \\
\text { Increased }\end{array}$ & $\begin{array}{l}298 \\
72 \\
34\end{array}$ & $\begin{array}{r}73.8 \\
17.8 \\
8.4\end{array}$ \\
\hline
\end{tabular}

Change in time spent at home

\begin{tabular}{l|l|l|} 
Decreased & 4 & 1.0 \\
Hasn't changed & 20 & 5.0 \\
Increased & 380 & 94.1 \\
\hline
\end{tabular}

\begin{tabular}{|l|l|l|} 
Change in computer or phone usage hours \\
\hline Decreased & 10 & 2.5 \\
Hasn't changed & 23 & 5.7 \\
Increased & 371 & 91.8 \\
\hline
\end{tabular}

\begin{tabular}{l|l|l|}
\hline * What technological tools do you own? \\
\hline Smart phone & 394 & 97.5 \\
Notebook PC & 113 & 28.0 \\
Laptop & 112 & 27.2 \\
Desktop Computer & 42 & 10.4 \\
Tablet & 37 & 9.3 \\
\hline
\end{tabular}

* Which social networking sites are you a member of?

\begin{tabular}{|l|l|l|}
\hline Instagram & 350 & 86.6 \\
YouTube & 233 & 57.7 \\
twitter & 190 & 47.0 \\
Facebook & 99 & 24.5 \\
Googleplus & 24 & 5.9 \\
Other* & 22 & 5.05 \\
\hline Change in the time you spend online & \multicolumn{2}{|l|}{} \\
\hline No Internet & 12 & 3.0 \\
Decreased & 16 & 4.0 \\
Hasn't changed & 25 & 6.2 \\
Increased & 351 & 86.9 \\
\hline Average time spent on websites in a day & \multicolumn{2}{|l}{} \\
\hline less than 1 hour & 29 & 7.2 \\
1-2 hours & 75 & 18.6 \\
3-4 hours & 149 & 36.9 \\
\hline 5-6 hours & 91 & 22.5 \\
7 hours or more & 60 & 14.9 \\
\hline * more than one option ticked. Tumblr, reddit, linkedin* \\
\hline
\end{tabular}




\section{Table 4. Statistical analysis of variables}

\begin{tabular}{|c|c|c|c|c|c|}
\hline \multirow{2}{*}{ Variables } & \multirow{2}{*}{ N } & \multirow{2}{*}{$\%$} & Perceived Stress Scale & Perceived Social Support Scale & Social Media Addiction Scale \\
\hline & & & $\overline{\mathbf{x}} \pm \mathrm{SD}$ & $\overline{\mathbf{x}} \pm \mathrm{SD}$ & $\overline{\mathbf{x}} \pm \mathrm{SD}$ \\
\hline \multicolumn{6}{|l|}{ Age Group } \\
\hline $18-20$ years & 196 & 48.5 & $31.61 \pm 7.91$ & $51.72 \pm 17.26$ & $54.95 \pm 16.11$ \\
\hline $21-23$ years & 187 & 46.3 & $33.08 \pm 7.67$ & $52.10 \pm 18.59$ & $58.68 \pm 16.78$ \\
\hline $24-26$ years & 16 & 4.0 & $29.18 \pm 8.48$ & $56.81 \pm 14.44$ & $46.25 \pm 16.27$ \\
\hline \multirow[t]{2}{*}{27 years and up } & 5 & 1.2 & $27.60 \pm 1.81$ & $62.60 \pm 15.61$ & $51.00 \pm 8.42$ \\
\hline & & & $\begin{array}{l}\mathrm{f}=2.541 \\
p>0.05\end{array}$ & $\begin{array}{l}\mathrm{f}=0.976 \\
p>0.404\end{array}$ & $\begin{array}{l}\mathrm{f}=3.947 \\
p<0.00\end{array}$ \\
\hline \multicolumn{6}{|l|}{ Department } \\
\hline Nursing & 230 & 56.9 & $30.90 \pm 7.29$ & $51.69 \pm 17.15$ & $56.76 \pm 15.96$ \\
\hline Midwifery & 174 & 43.1 & $33.79 \pm 8.24$ & $52.94 \pm 18.61$ & $55.67 \pm 17.35$ \\
\hline \multirow[t]{2}{*}{ Total } & 404 & 100 & $32.14 \pm 7.83$ & $52.23 \pm 17.78$ & $56.29 \pm 16.55$ \\
\hline & & & $\begin{array}{l}\mathrm{t}=-3.735 \\
p<0.00\end{array}$ & $\begin{array}{l}\mathrm{t}=-0.700 \\
p>0.484\end{array}$ & $\begin{array}{l}\mathrm{t}=0.654 \\
p>0.514\end{array}$ \\
\hline \multicolumn{6}{|l|}{ Class } \\
\hline 2. class & 164 & 40.6 & $31.57 \pm 8.35$ & $51.81 \pm 17.53$ & $56.40 \pm 16.79$ \\
\hline 3. class & 104 & 25.7 & $31.75 \pm 7.33$ & $53.16 \pm 16.44$ & $54.59 \pm 15.54$ \\
\hline \multirow[t]{2}{*}{4 class } & 136 & 33.7 & $33.13 \pm 7.49$ & $52.23 \pm 17.78$ & $57.45 \pm 17.03$ \\
\hline & & & $\begin{array}{l}\mathrm{f}=1.671 \\
p>0.189\end{array}$ & $\begin{array}{l}\mathrm{f}=0.278 \\
p>0.757\end{array}$ & $\begin{array}{l}\mathrm{f}=0.885 \\
p>0.414\end{array}$ \\
\hline \multicolumn{6}{|l|}{ Gender } \\
\hline Female & 345 & 97.0 & $32.56 \pm 7.84$ & $52.95 \pm 17.62$ & $56.92 \pm 16.75$ \\
\hline \multirow[t]{2}{*}{ Men } & 59 & 3.0 & $29.75 \pm 7.43$ & $48.00 \pm 18.32$ & $52.61 \pm 14.97$ \\
\hline & & & $\begin{array}{l}\mathrm{t}=2.565 \\
p<0.011\end{array}$ & $\begin{array}{l}\mathrm{t}=1.986 \\
p<0.048\end{array}$ & $\begin{array}{l}\mathrm{t}=1.854 \\
p>0.064\end{array}$ \\
\hline \multicolumn{6}{|l|}{ Marital status } \\
\hline Married & 12 & 3.0 & $28.75 \pm 4.35$ & $51.62 \pm 17.63$ & $55.00 \pm 10.71$ \\
\hline \multirow[t]{2}{*}{ Single } & 392 & 97.0 & $32.25 \pm 7.89$ & $55.00 \pm 10.71$ & $56.33 \pm 16.71$ \\
\hline & & & $\begin{array}{l}\mathrm{t}=-1.527 \\
p>0.127\end{array}$ & $\begin{array}{l}\mathrm{t}=3.997 \\
p<0.00\end{array}$ & $\begin{array}{l}\mathrm{t}=-0.274 \\
p>0.784\end{array}$ \\
\hline \multicolumn{6}{|l|}{ Living place } \\
\hline City center & 242 & 59.9 & $31.80 \pm 7.36$ & $52.72 \pm 18.67$ & $55.84 \pm 15.26$ \\
\hline District & 97 & 24.0 & $32.27 \pm 8.57$ & $48.29 \pm 18.74$ & $56.29 \pm 19.81$ \\
\hline \multirow[t]{2}{*}{ Village } & 65 & 16.1 & $33.20 \pm 8.37$ & $52.23 \pm 17.78$ & $53.09 \pm 16.55$ \\
\hline & & & $\begin{array}{l}\mathrm{f}=0.824 \\
p>0.439\end{array}$ & $\begin{array}{l}\mathrm{f}=1.928 \\
p>0.147\end{array}$ & $\begin{array}{l}\mathrm{f}=2.984 \\
p<0.052\end{array}$ \\
\hline
\end{tabular}


There is a negative significant relationship between students' perceived stress and "perceived social support" $(r=-.426$; $p=0.000)$. Perceived stress and social support sub-dimensions "family ( $\mathrm{r}=-.444 ; p=0.000)$ ", "friend" $(\mathrm{r}=-.339 ; p=0.000)$, and "special person" ( $\mathrm{r}=-.229 ; p=0.000)$ was found to have a significant negative correlation. Social media addiction subdimensions of perceived stress ("Virtual Tolerance" $(r=, 339$; $p=0.000)$ and "Virtual Communication" $(r=.239 ; p=0.000)$ and "Social media addiction" ( $r=.319 ; p=0.000)$ there was a significant positive correlation. It was observed that there was a significant negative correlation between perceived social support and total social media addiction scores $(r=-.106 ; p=0.05)$. It was determined that there was a negative, significant and strong relationship ( $\mathrm{r}=-.148 ; p=0.000$ ) between social support family sub-dimension and social media addiction (Table 5).

\section{Discussion}

This study examines the relationship between university students' perceptions of stress, perceptions of social support, and social media addiction during the COVID-19 pandemic.

In this study, it was determined that the stress level, social support perception level and social media addiction levels of the participants were above the average. It was observed that the perceived stress scores of the 21-23 age group were higher than the other groups in the age group variable.

In the study conducted by Göksu and Kumcagız (2020), it was determined that individuals' perceived stress and anxiety levels in the COVID-19 epidemic were moderate (3). In the same study, it was reported that individuals in the 20-29 age group perceived the epidemic process as more stressful than other older age groups (3). Cao et al. (2020b), found that stress and anxiety levels were high during the COVID-19 outbreak in their study with university students in China. Toreles et al. (2020), reported in their study that the level of age-related stress changes and that young and old people experience higher levels of stress. Going out of the routine of encountering an unexpected situation, having restrictions at home, restricting their freedom, fear of losing loved ones may be the reasons for the increase in the stress perception of young people.

In this study, the level of perceived stress and social support were found to be higher in women. In the study of Wang et al. (2020), on the psychological reactions in the COVID-19 epidemic, it was found that women experience higher levels of anxiety than men. In studies, it has been reported that the COVID-19 epidemic increases the level of stress and anxiety in individuals, and the level of anxiety is higher in women $(9,31)$. This research finding is in line with the literature. Women are more negatively affected by stress than men. It is thought that the high-stress level of women stems from traditional gender roles and this situation continues in extraordinary situations.

There was a negative relationship between perceived stress and perceived social support. There was a positive relationship between perceived stress and social media addiction. And there was a negative relationship was determined between social

Table 5. Correlation of students' PSS, PSSS and SMAS sub-dimension and total scores

\begin{tabular}{|c|c|c|c|c|c|c|c|c|}
\hline Variables & 1 & 2 & 3 & 4 & 5 & 6 & 7 & 8 \\
\hline $\begin{array}{l}\text { 1PSS } \\
\text { Total }\end{array}$ & 1 & & & & & & & \\
\hline $\begin{array}{l}2 \text { PSSS } \\
\text { Family }\end{array}$ &,$- 444 * *$ & 1 & & & & & & \\
\hline $\begin{array}{l}\text { 3PSSS } \\
\text { Friend }\end{array}$ &,$- 339 * *$ &, $579 * *$ & 1 & & & & & \\
\hline $\begin{array}{l}\text { 4PSSS } \\
\text { Special Person }\end{array}$ &,$- 229 * *$ &, $373 * *$ &, $270 * *$ & 1 & & & & \\
\hline $\begin{array}{l}\text { 5PSSS } \\
\text { Total }\end{array}$ &,$- 426^{* *}$ &, $817^{* * *}$ &, $765^{* *}$ &, $747^{* *}$ & 1 & & & \\
\hline $\begin{array}{l}6 \text { SMAS-AF } \\
\text { Virtual Tolerance }\end{array}$ &, $339 * *$ & $-148^{* *}$ &,- 084 &,- 030 &,$- 108^{*}$ & 1 & & \\
\hline $\begin{array}{l}7 \text { SMAS-AF } \\
\text { Virtual communication }\end{array}$ &, $239 * *$ &,$- 121^{*}$ &,- 073 &,- 013 &,- 085 &, $690 * *$ & 1 & \\
\hline $\begin{array}{l}8 \text { SMAS-AF } \\
\text { Total }\end{array}$ &, $319 * *$ & $-148^{* * *}$ &,- 086 &,- 024 &,$- 106^{*}$ &, $934 * *$ &, $903 * *$ & 1 \\
\hline
\end{tabular}


support and social media addiction. Eker et al. (2001) stated in their studies that the support of family and close friends is a predictor of health. In the same study, it was reported that family ties are also important sources for physical health (25). It can be said that social media addiction increases in cases where family support decreases.

Increasing stress night cause students to turn to social media. Research findings have led to an increase in the duration of students staying at home, especially during the COVID-19 epidemic, along with cleanliness, distance and restriction. In this study, almost all of the students reported that the time they stayed at home increased, that there was a change in the hours of computer or phone use due to the pandemic and that the time they spent on the internet increased. Çiftçi reports in his study that gender, age, educational status and duration of internet users play a decisive role in social media addiction and duration of use (23). Studies have revealed that the perception of social support is associated with various variables such as school success $(11,32)$, academic and social skills (33). Therefore, it can be said that students who receive parents, friends and school support are better socially and emotionally. It is thought that extraordinary situations are periods when family support should be more especially for young people.

In the study, $36.9 \%$ of the students reported that they spent an average of 3-4 hours a day for social networking sites, instant messaging programs, online games and all other websites, and $14.9 \%$ reported that they spent seven hours or more on the Internet. It was seen that most of the participants actively use the social media platforms Instagram, Youtube and Twitter.

In the literature, it was found that those who have social media membership have higher internet addiction scores than those who do not $(34,35)$. When the relevant literature is examined, there are studies showing that social media use is associated with internet addiction, It has been reported that the increase in the time spent on the internet is one of the factors affecting internet addiction (35-37). In studies on technology addiction, it has been reported that those who have an inadequate relationship with their families and who cannot spend time effectively with their families are among the risk factors that increase the use of technology $(35,38)$.

In the literature, there are studies stating that university students use the internet as a means of entertainment $(24,39)$ and studies stating that they use the internet for research or access to academic information $(23,26,40)$. In the study conducted by Karadağ and Yücel (2020), 3/4 of the students stated that they continue their distance education from their computers or tablets and 32\% from their smartphones (41). The results of the study show parallelism with the literature. However, with the data obtained from the research, we can say that the majority of students are obliged to mobile phones and computers in a period when going out is limited during the Covid-19 pandemic period. This situation should be considered as an important factor in increasing the level of social media addiction by increasing the level of stress.

The limitations of the study can be stated as the inability to reach the entire universe due to the remote collection of research data via Google form. It is an important study in terms of evaluating the impact of the pandemic on university students as the strengths of the research. The strengths of the research are that the students are independent when filling out the forms, not being given a certain time, and allowing the students to fill out the form whenever they want. Students were not under pressure about their attitudes and behaviors. Therefore the data is valuable.

In conclusion, this study, which focuses on the relationships between the perception of stress social support and social media addiction, contributes to the literature in terms of understanding the COVID-19 experiences of university students. Studies on the subject show the importance of virtual interaction environments for students. Considering that changes and extraordinary situations in technology are a part of individuals' lives, researchers should continue to examine students' tendencies in technology use and their effects on individual life.

Unusual situations affect individuals negatively. The COVID-19 pandemic will go down in history as one of these periods. Young people who go out of their daily routines and whose freedoms are restricted should be seen as the most affected group during these periods. In such cases, the social support powers of the students should be the greatest support from family, friends, spouses and special friends. It should be noted that the interest in online networks may increase in students who do not receive sufficient social support and it will take the form of addiction after a while.

In addition to studies examining the relationships between stress, perception of social support and social media addictions in university students during the COVID-19 epidemic, research on different variables that affect students' social media attitudes will enrich the relevant literature. Effective use of social media tools by students in extraordinary situations where there is no face-to-face education can lead to a number of positive gains. The aspects of strengthening student-student and student-teacher relations and promoting a supportive learning environment should be considered and developed. 


\section{References}

1. Yavaş Çelik M. The effect of staying at home due to COVID-19 outbreak on nursing students' life satisfaction and social competencies. Perspect Psychiatr Care 2021; 57(2): 655-59.

2. Krizanova O, Babula P, Pacak K. Stress, catecholaminergic system and cancer. Stress 2016; 19(4): 419-428.

3. Göksu Ö, Kumcağız H. Perceived stress level and anxiety levels in ındividuals in covid-19 outbreak. Turkish Studies 2020; 15(4): 463-479.

4. Toreles J, O'Higgins M, Maia JM, Venrriglio A. The outbreak of Covid-19 coronavirus and its impact on global mental health. Int J Soc Psychiatry 2020; 66(4): 317-320.

5. Sürme Y. Stres, stresle ilișkili hastalıklar ve stres yönetimi. Uluslararası Sosyal Araştırmalar Dergisi 2019;12(64): 525-529.

6. Zadahmad M, Torkan H. Investigation of the multiple relationships between early maladaptive schemas and coping styles with anxiety. Int J Educ Psychol Res 2016; 2(1): 49-53.

7. Joos A. Psychosomatic medicine and covid-19 pandemic. Psychother Psychosom 2020; 89(4): 263-264.

8. Czeisler ME, Lane RI, Petrosky E, et al. Mental health, substance use, and suicidal ideation during the COVID-19 pandemic-United States. MMWR Morb Mortal Wkly Rep 2020; 69(32):1049-1057.

9. Duan L, Zhu G. Psychological interventions for people affected by the Covid-19 epidemic. Lancet Psychiatry 2020; 7(4): 300-302.

10. Şahin C, Yağcı M. Sosyal medya bağımlılığı ölçeği-yetișkin formu: geçerlilik ve güvenirlik çalışması. Ahi Evran Üniversitesi Kırşehir Eğitim Fakültesi Dergisi 2017; 18(1): 523-538.

11. Deniz E, Kazu H. Algılanan sosyal desteğin ortaokul öğrencilerinin sosyal medya tutumlarına etkisinin yol analizi ile incelenmesi. Elektronik Sosyal Bilimler Dergisi 2021; 20(78): 892-910.

12. Banyai F, Zsila A, Kiraly 0 , et al. Problematic social media use: results from a large-scale nationally representative adolescent sample. PLoS One 2017; 12(1):e0169839..

13. Tutgun-Ünal A, Deniz L. Development of the social media addiction scale. AJIT-e: Online Academic Journal of Information Technology 2015; 6(21): 5170 .

14. Yıldız E, Koçak O. Üniversite öğrencilerinde sosyal medya bağımlılı̆̆ı ve algılanan sosyal destek arasındaki ilişkinin değerlendirilmesi. Toplum ve Sosyal Hizmet 2020; 31(3): 1102-1126.

15. Harmancı H, Dayıoğlu H, Kırkpınar SN. Üniversite öğrencilerinin sosyal medya bağımlılı̆ı ile olumlu değerlendirilme korkusu ve olumsuz değerlendirilme korkusu arasındaki ilișkinin incelenmesi. Karatay Sosyal Araştırmalar Dergisi 2019; S(3): 242-255.

16. Sarıçam H, Adam-Karduz FF. Sosyal medya kullanım bozukluğu ölçeği’nin türk kültürüne uyarlanması: Geçerlik ve güvenirlik çalıșması. Eğitimde ve Psikolojide Ölçme ve Değerlendirme Dergisi 2018; 9(2): 116-135.

17. Çetin C, Anuk Ö. Covid-19 pandemi sürecinde yalnızlık ve psikolojik dayanıklıık: Bir kamu üniversitesi öğrencileri örneklemi. Avrasya Sosyal ve Ekonomi Araștırmaları Dergisi 2020; 7(5): 170-189.

18. Internet World Stats. Usage and population statistics. 2021. http://www. internetworldstats.com/stats.htm. Accessed 15 Jan 2021.

19. Türkiye internet kullanımı ve sosyal medya istatistikleri 2020, https:// dijilopedi.com/2020-turkiye-internet-kullanimi-ve-sosyal-medyaistatistikleri. Accessed 5 Jan 2021.
20. YÖK, Basın açıklaması. 2020. Https://www.yok.gov.tr/Sayfalar/Haberler/2020/ universitelerdeuygulanacak-uzaktan-egitime-iliskin-aciklama.aspx. Accessed 1 Jan 2021.

21. Turan Z, Gürol A. Eğitimde acil bir dönüşüm: Covid-19 pandemisi döneminde çevrim içi ders alan üniversite öğrencilerinin stres algıları ve görüșleri. HAYEF: Journal of Education 2020; 17(2): 222-242.

22. Eskin $M$, Harlak H, Demirkıran F, Dereboy Ç. Algılanan stres ölçeğinin türkçeye uyarlanması: güvenirlik ve geçerlik analizi. Yeni Symposium 2013; 51(3): 132-140.

23. Çiftçi H. Üniversite öğrencilerinde sosyal medya bağımlılı̆̆ı. MANAS Sosyal Araștırmalar Dergisi 2018; 7(4): 417- 434.

24. Uzun Ö, Yıldırım V, Uzun E. Dikkat eksikliği hiperaktivite bozukluğu olan ergenlerde sosyal medya kullanım alışkanlıkları ve sosyal medya bağımlılı̆̆, benlik saygısı ve algılanan sosyal destek ilișkisi. Turkish Journal of Family Medicine and Primary Care 2016; 10 (3): 142-147.

25. Eker D, Arkar H, Yaldız H. Çok boyutlu algılanan sosyal destek ölçeğinin gözden geçirilmiş formunun faktör yapısı geçerlik ve güvenirliği. Turk Psikiyatri Derg 2001; 12(1): 17-25.

26. Yılmazsoy B, Kahraman M. Üniversite öğrencilerinin sosyal medya bağımlılığı ile sosyal medyayı eğitsel amaçı kullanımları arasındaki ilișkinin incelenmesi: Facebook Örneği. Journal of Instructional Technologies \& Teacher Education 2017; 6 (1): 9-20.

27. Cohen S, Kamarck T, Mermelstein RA. Global measure of perceived stress. J Health Soc Behav 1983; 24(4): 385-396.

28. Zimet GD, Dahlem NW, Zimet SG, et al. The multidimensional scale of perceived social support. J Pers Assess 1988; 52(1): 30-41.

29. Cao W, Fang Z, Hou G, et al. The psychological impact of the covid-19 epidemic on college students in China. Psychiatry Res 2020; 287: 112934.

30. Wang C, Pan R, Wan X, et al. Immediate psychological responses and associated factors during the Initial stage of the 2019 coronavirus disease (covid-19) epidemic among the general population in china. Int J Environ Res Public Health 2020; 17: 1729.

31. Zhang W, Wang K, Yin L, et al. Mental health and psychosocial problems of medical health workers during the covid-19 epidemic in China. Psychother Psychosom 2020; 89(4): 242-250.

32. Çolak TS, Doğan U. Does the use of social media ensure social support and happiness? International Online Journal of Educational Sciences 2016; 8(4): 229-240.

33. Eroğlu A, Bayraktar S. Investigation of variables associated with internet addiction. International Journal of Social Sciences and Education Research 2017; 3(1): 184-199.

34. Öner K, Arslantaş H. Internet addiction in high school students, affecting factors and relationship between internet addiction and depression risk. Jurnal Medical Brasovean 2018; 1: 38-49.

35. Yüksel R, Kocairi C, Arslantaş H, Söylemez B. Ergenlerde internet bağımlıı̆̆ını etkileyen faktörler. Balıkesir Sağlık Bilimleri Dergisi 2020; 9(1): 19-28.

36. Tsitsika A, Critselis E, Kormas G, et al. Internet use and misuse: a multivariate regression analysis of the predictive factors of internet use among Greek adolescents. Eur J Pediatr 2009; 168(6): 655-5.

37. Yang SC, Tung CJ. Comparison of Internet addicts and non-addicts in Taiwanese high school. Comput Hum Behav 2007; 23(1): 79-96.

38. Efe SY, Erdem E, Vural B. Lise öğrencilerinde siber zorbalık ve internet bağımlılı̆ı. Bağımlılık Dergisi 2021; 22(4): 465-473 
39. Karasu F, Bayır, B, Çam HH. Üniversite öğrencilerinin internet bağımlılı̆̆ ile sosyal destek arasındaki ilișkinin incelenmesi. Sosyal Bilimler Dergisi 2017; 7 (14): $374-388$

40. Becan C. Sosyal medya bağımlılı̆̆ının haber takibi motivasyonları üzerine etkisi. Erciyes Illetișim Dergisi 2018; 5(3): 238-256.
41. Karada E, Yücel C. Yeni tip koronavirüs pandemisi döneminde üniversitelerde uzaktan eğitim: lisans öğrencileri kapsamında bir değerlendirme çalıșması. Yükseköğretim Dergisi 2020; 10(2): 181-192. 